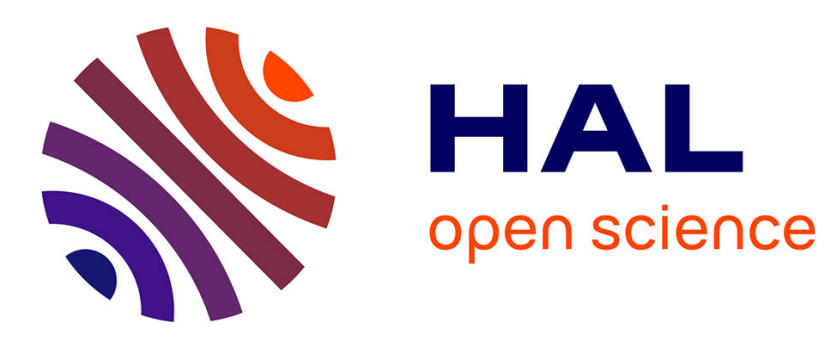

\title{
Mathematical programming model for centralised master planning in ceramic tile supply chains
}

M M Alemany Diaz, Jorge Boj Viudez, Josefa Mula Bru, F C L Esteban

\section{To cite this version:}

M M Alemany Diaz, Jorge Boj Viudez, Josefa Mula Bru, F C L Esteban. Mathematical programming model for centralised master planning in ceramic tile supply chains. International Journal of Production Research, 2010, 48 (17), pp.5053-5074. 10.1080/00207540903055701 . hal-00606290

\section{HAL Id: hal-00606290 \\ https://hal.science/hal-00606290}

Submitted on 6 Jul 2011

HAL is a multi-disciplinary open access archive for the deposit and dissemination of scientific research documents, whether they are published or not. The documents may come from teaching and research institutions in France or abroad, or from public or private research centers.
L'archive ouverte pluridisciplinaire HAL, est destinée au dépôt et à la diffusion de documents scientifiques de niveau recherche, publiés ou non, émanant des établissements d'enseignement et de recherche français ou étrangers, des laboratoires publics ou privés. 


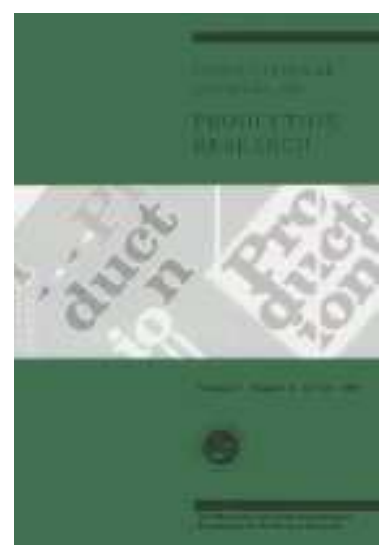

\section{Mathematical programming model for centralised master planning in ceramic tile supply chains}

\begin{tabular}{|r|l|}
\hline Journal: & International Journal of Production Research \\
\hline Manuscript ID: & TPRS-2008-IJPR-0853.R1 \\
\hline Manuscript Type: & Original Manuscript \\
\hline Author: & O6-Mar-2009 \\
\hline Complete List of Authors: & $\begin{array}{l}\text { Alemany Diaz, M M; Valencia Polytechnic University, Centro de } \\
\text { Investigación de Gestión e Ingeniería de Producción; Valencia } \\
\text { Polytechnic University, Organización de Empresas } \\
\text { Boj Viudez, Jorge; Universidad Politécnica de Valencia, Centro de } \\
\text { Investigación de Gestión e Ingeniería de Producción } \\
\text { Mula Bru, Josefa; Universidad Politécnica de Valencia, Centro de } \\
\text { Investigación de Gestión e Ingeniería de Producción } \\
\text { Esteban, F C L; Universidad Politécnica de Valencia, Centro de } \\
\text { Investigación de Gestión e Ingeniería de Producción }\end{array}$ \\
\hline Keywords: & $\begin{array}{l}\text { MIXED INTEGER LINEAR PROGRAMMING, SUPPLY CHAIN } \\
\text { MANAGEMENT, MASTER PRODUCTION SCHEDULE, MAKE TO STOCK } \\
\text { PRODUCTION }\end{array}$ \\
\hline Keywords (user): & $\begin{array}{l}\text { Master planning, supply chain, ceramic sector, mixed-integer linear } \\
\text { programming model }\end{array}$ \\
\hline & \\
\hline
\end{tabular}

\section{S) ScholaroNE \\ Manuscript Central}




\title{
Mathematical programming model for centralised master planning in ceramic tile supply chains ${ }^{* *}$
}

\begin{abstract}
The object of this article is to develop a centralised replenishment, production, and distribution model for ceramic tile supply chains. These supply chains are assumed to be multi-item, multisupplier, multi-facility, multi-type and multi-level distribution centres. The model deals with multiperiod master planning where sourcing considerations for replenishments, production facilities, and distribution centres are important to maximise an objective function involving the total net profit. This model is deterministic and has been formulated as a mixed-integer linear programming (MILP) model. An example based on modifications of real-world industrial problems is presented.
\end{abstract}

Keywords: Master planning, supply chain, ceramic sector, mixed-integer linear programming model

\footnotetext{
** This research has been carried out in the framework of a project funded by the Science and Technology Ministry of the Spanish Government, entitled "Hierarchical methodology in the context of uncertainty in the collaborative planning of a supply-distribution chain/network. Application to the ceramic sector". Ref. DPI2004-06916-C02-0.
} 


\title{
Mathematical programming model for centralised master planning in

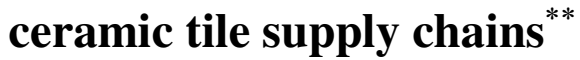

\author{
M.M.E. Alemany*, J.J. Boj, J. Mula, Francisco C. Lario \\ Centro de Investigación de Gestión e Ingeniería de Producción (CIGIP) \\ Universidad Politécnica, Valencia, Spain
}

\begin{abstract}
The object of this article is to develop a centralised replenishment, production, and distribution model for ceramic tile supply chains. These supply chains are assumed to be multi-item, multisupplier, multi-facility, multi-type and multi-level distribution centres. The model deals with multiperiod master planning where sourcing considerations for replenishments, production facilities, and distribution centres are important to maximise an objective function involving the total net profit. This model is deterministic and has been formulated as a mixed-integer linear programming (MILP) model. An example based on modifications of real-world industrial problems is presented.
\end{abstract}

Keywords: Master planning, supply chain, ceramic sector, mixed-integer linear programming model

\footnotetext{
** This research has been carried out in the framework of a project funded by the Science and Technology Ministry of the Spanish Government, entitled 'Hierarchical methodology in the context of uncertainty in the collaborative planning of a supply-distribution chain/network. Application to the ceramic sector'. Ref. DPI2004-06916-C02-0.

* Corresponding author. María del Mar Eva Alemany, Dpto. Organización de Empresas, Universidad Politécnica de Valencia, Camino de Vera s/n, 46022, Valencia, SPAIN. Tel.: + 34963877007 ext. 76868. Fax: +34 $96 \quad 387 \quad 76 \quad 89$. E-mail addresses: mareva@omp.upv.es, jorbojvi@upvnet.upv.es, fmula@cigip.upv.es, fclario@ cigip.upv.es.
} 


\section{Introduction}

Many firms have attempted to optimise different functions separately (e.g., replenishment, production, and distribution), but this approach limits any possible increase in profit. Therefore, an approach based on the integration of different functions in the supply chain (SC) into a single optimisation model has proved significantly relevant for companies that have adopted it (Park, 2005). This approach is also known as centralised modelling. Reviews of centralised mathematical programming planning models within the SC context are provided in Bhatnagar et al. (1993), Thomas and Griffin (1996), and Erengüç et al. (1999).

In this article, we consider the master planning problem for replenishment, production, and distribution in ceramic tile SC. The objective is to maximise the total net profit in SC characterised as multi-item, multi-supplier, multi-facility, multi-type and multi-level distribution centres. The problem addressed originates from a work carried out in a research project framework with an important ceramic tile SC. The project has developed a conceptual framework (Alarcón et al. 2007) comprised of five views (physical, organisational, informational (Boza et al. 2007), decisional (Pérez et al. 2007), and functional) that characterise the collaborative planning process within a hierarchical context. The hierarchical aspects of this framework are mainly based on a methodology for the design and operation of hierarchical production planning systems proposed by Vicens et al. (2001). This research project examines centralised and distributed decision-making in a collaborative context. However, this work is restricted to the centralised approach. In this context, a generic mixed-integer linear programming (MILP) model, dubbed MP-RDSINC, has been developed to support the decision-making process related to the master planning of replenishment, production, and distribution in ceramic tile SC. The main contribution of this article to the field of production research is a practical application of mathematical programming to the ceramic tile SC using a numerical example based on a real-world SC production planning problem. The ceramic tile SC presents a series of peculiarities characteristic of the sector, some of which may be reviewed in Alemany et al. (2008). Other mathematical programming applications for SC planning may be found in von Lanzenauer and Pil-Glombik (2002), Keipl and Pinedo (2004), and Peidró et al. (2007). Readers may also refer to Section 2 of this article.

The rest of this article is arranged as follows. Section 2 presents a literature review about the research topic. Section 3 describes the problem being studied. In Section 4, we present a deterministic MILP model to solve the replenishment, production, and distribution problem. Section 5 reports a detailed example based on a real-world problem to validate and evaluate the model proposed. Section 6 offers conclusions and further research.

\section{Literature review}

This section reviews mathematical programming models from two approaches: first, those developed for centralised SC master planning in general, and second, those designed for the master planning of firms in the ceramic sector in particular. The latter have been taken from either an SC or a single-firm perspective.

McDonald and Karimi (1997) developed a multi-product, multi-stage and multi-period MILP model for chemical supply chains within the block of centralised mathematical programming models for SC master planning. Grouped into families, the products compete for the limited capacity of resources. Demand uncertainty is addressed through safety stocks. Escudero et al. (1999) formulated a multi-product, multi-stage and multi-period linear programming (LP) model that included multiple demand sources, alternative bill of materials, substitution parts, effective usage dates, capacity constraints, and different methods to obtain components (standard and expedition). These authors also proposed a stochastic version of the problem. Timpe and Kallrath (2000) 
described a multi-product, bi-stage MILP model that considered production, distribution, and marketing aspects and also assumed varying time periods for production and distribution. Jayaraman and Pirkul (2001) described a multi-product, multi-stage and multi-period MILP model. It included strategic decisions (warehouse and plant localisation) and tactical decisions (product mix, shipments, etc.) and used a heuristic technique based on Lagrangean relaxation to solve the problem. Lavoie and Abdulnour (2003) described an MILP model that considered four first-tier suppliers and a factory to contribute to coordination at a tactical level. This model was multi-periodbased and minimised the total production, inventory and distribution costs. It also used a simulation model to analyse costs at the distribution level by considering vehicle routing, direct shipping, and an intermediate consolidation centre. Lin and Chen (2004) developed a multi-product, multi-stage and multi-period integer linear programming (ILP) model that considered different time periods, i.e., days and months. Wu and Golbasi (2004) proposed an MILP model to solve a multi-item, singlestage, multi-facility lot-sizing problem. It employed Lagrangean decomposition to achieve the model resolution. Park (2005) presented an MILP model to jointly solve the production and distribution planning problem in a multi-plant, multi-retailer, multi-item and multi-period logistic environment whose objective was to maximise the total net profit. Although production capacity was assumed to be known, it was necessary to determine the number of vehicles required for distribution from plants to shops. Spitter et al. (2005) proposed an MILP for capacity-constrained supply chain operations planning that used planned lead times with multi-period capacity consumptions where items may be allocated to multiple resources. Schulz et al. (2005) presented a multi-product, multi-stage and multi-period mixed-integer nonlinear programming (MINLP) model applied to a petrochemical SC to consider different types of delivery. Ekşioğlu et al. (2006) formulated a uni-product model for transport and production planning as a graph associated with MILP formulation. Ekşioğlu et al. (2007) extended this model to a multi-model product and used Lagrangean decomposition to solve it. Lim et al. (2006) presented a hybrid model that comprised not only an MILP model for the decision-making process in the production and inventory capacities in each SC node, but also a simulation model for production and distribution planning. Oh and Karimi (2006) presented an LP model for the production and distribution planning of a global chemical company. Bilgen and Ozkarahan (2007) developed an MILP model for bulk grain blending and shipping. Meijboom and Obel (2007) developed an MILP model for production planning in an SC that was applied to a pharmaceutical company.

With regard to mathematical programming models for ceramic SC planning, Liberatore and Miller (1985) proposed a hierarchical production planning model with two decision levels based on mathematical programming models for planning in a ceramic SC. This model focused on production and distribution stages. It did not consider lot sizing, percentage of first qualities and defects, and part supplying limitations by suppliers. Furthermore, and unlike this article, it considered a single level for the distribution stage. Other works on production planning in the ceramic SC were Özdamar and Bozyel (1998), Özdamar and Birbil (1998), and Özdamar and Birbil (1999). These works addressed the problem known as the Capacitated Lot Sizing and Loading Problem (CLSLP) and mainly focused on the production stage without considering the replenishment of raw materials and components (RMs), or the subsequent distribution of finished goods (FGs). After reviewing the literature, we were unable to find studies on mathematical models for the master planning of replenishment, production, and distribution for a ceramic tile SC, which is the main objective of this article.

\section{Problem description}

SCs belonging to the ceramic sector present a series of peculiarities, which are described here. Figure 1 provides an overview of the problem resources in terms of replenishment, production, and distribution (physical view). It is assumed that the possibilities of flow between the nodes of the various stages (arcs), as well as the parts, components, raw materials (RMs), and finished goods or articles (FGs) that might circulate through them, have been considered beforehand. The existence 
of several production plants situated in various geographical locations is also assumed. These production plants are supplied with various RMs provided by different suppliers with a limited supply capacity. This represents the total capacity of the supplier assigned to the SC under study because it is assumed that RM suppliers may supply production plants belonging to other SCs.

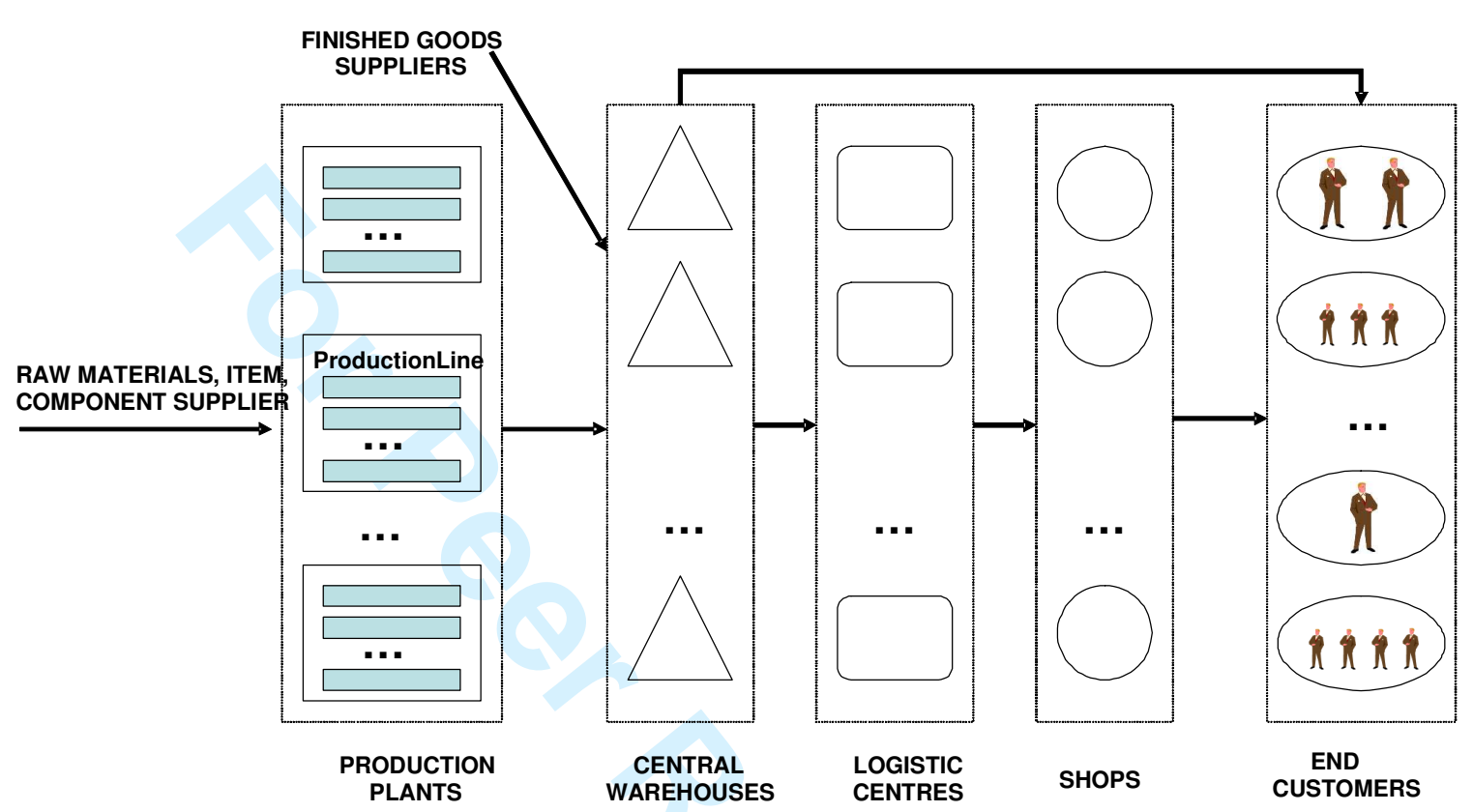

Figure 1: Multi-supplier, multi-plant, multi-type-multilevel-distribution centres, multi-item and multi-period logistic model.

Each production plant has one or several production lines (processors in parallel) with a limited capacity. Different FGs can be processed by each production line. There are FGs with high added value that are manufactured only in production plants; others may be partly subcontracted, while some may be totally subcontracted to external suppliers (normally products with a low added value). FGs are grouped into product families for production and commercial reasons. A product family is defined as a group of FGs of identical use (flooring or coverings), format (size), grout (white or red), and whose preparation on production lines is similar. This is done to minimise setup times and costs. Changeovers from one product family to the next incur setup costs owing to the time spent in changing, for instance, moulds (Özdamar and Bozyel, 1998). Lines may not be standardised, in which case, each product family can be processed according to specific facilities with the appropriate technical features. Therefore, not all production lines are capable of processing all the product families, although the product families that may be processed on each line is known. Given the important setup times between product families on production lines, production within a minimum number of consecutive time periods should be carried out whenever a production line is set up for a specific product family (minimum run length). Item setups among the products belonging to the same product family also exist. Because of technological factors involved in the production process itself, when a certain product is manufactured on a specific line, it should be produced in an equal or greater amount than the minimum lot size. This is partly because a certain percentage of defects occurs during the production process, and only a percentage of the manufactured items may be sold as first quality FG.

In the majority of the production planning models developed at the tactical level, the capacities at each stage are aggregated and setup changes are not explicitly considered. However, if at this level the setup times involve an important consumption capacity and have been completely ignored, this 
may lead to an overestimation of the real capacity availability which, in turn, may lead to unfeasible events during the subsequent disaggregation of tactical plans. Considerable savings may be also be achieved through optimum lot-sizing decisions. However, accounting for setup times at the tactical level would mean simultaneously including decisions about the allocation and lot sizing of production. This problem is known as the Capacitated Lot-Sizing and Loading Problem (CLSLP) (Özdamar and Birbil, 1998). Given the lengthy setup times involved in the manufacturing of ceramic floorings and coverings, these setup times need to be considered at the tactical level. This work aims to solve this problem within the CLSLP framework.

The distribution of several FGs (multi-item) from production plants to end customers is carried out in various stages (multi-level) by different types of distribution centres (multi-type), such as central warehouses, logistic centres and shops. Neither manufactured nor subcontracted FGs can be stored in manufacturing plants. So they are sent to the first distribution level, which is made up of a number of central warehouses with a limited storage capacity. Outgoing FGs from central warehouses are designed to not only cover the demand of certain end customers (for instance, independent distributors that do not belong to the firm, construction firms, etc.), but to also supply logistics centres. Logistics centres, unlike warehouses, do not have the required storage capacity and only supply FGs to shops that have been previously assigned to them. Finally, shops, which do not have storage capacity, attend to end customers' demands. Although this type of SC attempts to achieve a maximum customer service level, backorders are permitted in both central warehouses and shops. However, backorders quantities are limited to a certain demand percentage to ensure the accomplishment of an objective customer service level defined by the SC. This is a usual situation in the ceramic tile sector, given its limited production flexibility owing to setup costs and times.

\section{Model formulation}

A centralised MILP model has been developed to solve the planning problem of replenishing RMs in production plants, producing and subcontracting FGs, and distributing FGs. This model assumes that the decisions made about FGs and product families, which may be manufactured on each line, and those decisions made about establishing distribution routes for the different FGs throughout the network, have been previously made and are known for certain. The objective is to maximise the total net profit over the time periods of the planning horizon by: (i) optimising the total SC network starting with replenishment and going through production on to distribution; and (ii) optimising the production in the production nodes. To accomplish the latter, production planning in plants will have to simultaneously deal with not only the allocation of FGs to production lines with a limited capacity, but also with the determination of lot sizing.

The following MILP formulation, MP-RDSINC, provides a deterministic model for both multisupplier, multi-plant, multi-type, multi-level distribution centres and multi-item and multi-period logistic problems when product demands are known with certainty. The indices, sets of indices, model parameters, and decision variables are described in Tables 1-4, respectively. With the proposed definition of the sets of indices, the model is able to capture any flow of materials among the nodes belonging to the various stages of the physical overview (Figure 1).

[Insert Table 1 about here]

[Insert Table 2 about here]

[Insert Table 3 about here]

[Insert Table 4 about here] 
MP-RDSINC:

$$
\begin{aligned}
& \operatorname{Max} \sum_{t} \sum_{i}\left(\sum_{a} p a_{i a} * V E A_{i a t}+\sum_{w} p w_{i w} * V E T K_{i w t}\right) \\
& -\sum_{t} \sum_{p} \sum_{r \in R p(p)} \sum_{c \in C r(r)} \cos t t p_{c r p}{ }^{*} C T P_{c r p t}-\sum_{t} \sum_{p} \sum_{l \in L p(p)} \sum_{i \in I l(l)} \cos t p_{i l p}{ }^{*} M P_{i l p t} \\
& -\sum_{t} \sum_{p} \sum_{l \in L p(p)} \sum_{f \in F l(l)} \operatorname{costsetupf}_{f l p} * Z F_{f l p t}-\sum_{t} \sum_{p} \sum_{l \in L p(p)} \sum_{i \in I l(l)} \operatorname{costsetupi}_{i l p} * Z I_{i l p t}
\end{aligned}
$$

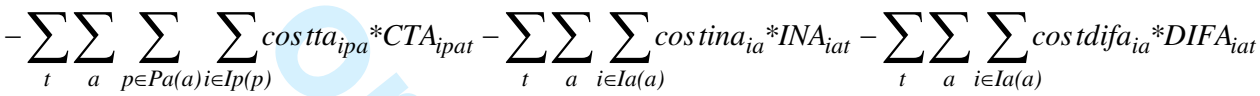

$$
\begin{aligned}
& -\sum_{t} \sum_{i} \sum_{b \in B i(i)} \sum_{a \in A b(b)} \operatorname{costsc}_{i b} * C S C_{i b a t}-\sum_{t} \sum_{a} \sum_{q \in Q a(a)} \sum_{i \in I q(q)} \cos _{t t c l_{i a q}} * C T C L_{i a q t} \\
& -\sum_{t} \sum_{q} \sum_{w \in W q(q)} \sum_{i \in I w(w)}{\cos t t t k_{i q w}}^{*} C_{T T K} K_{i q w t}-\sum_{t} \sum_{w} \sum_{i \in I w(w)} \cos \operatorname{tdift}_{i w} * \operatorname{DIFTK}_{i w t}
\end{aligned}
$$

subject to:

$$
\begin{aligned}
& I N C_{c p t}=I N C_{c p t-1}+\sum_{r \in R c(c)} C T P_{c r p t}-\sum_{i \in I c(c)}\left(v_{i c} * \sum_{l \in L p(p)} M P_{i l p t}\right) \quad \forall c, p, t \\
& I N C_{c p t} \geq s s c_{c p} \quad \forall c, p, t \\
& \sum_{p} C T P_{c r p t} \leq c a_{c r t} \quad \forall c, r \in R c(c), t \\
& \sum_{f \in F l(l)} \text { tsetupf }_{f l p} * Z F_{f l p t}+\sum_{i \in I l(l)}\left(t_{\text {setupi }} i_{i l p} * Z I_{i l p t}+t f a b_{i l p} * M P_{i l p t}\right) \leq c a f_{l p t} \quad \forall p, l \in L p(p), t \\
& M P F_{f l p t}=\sum_{i \in I f(f)} M P_{i l p t} \quad \forall p, l \in L p(p), f \in F l(l), t \\
& M P_{i l p t} \geq l m i_{i l p} * X_{i l p t} \quad \forall p, l \in L p(p), i \in \operatorname{Il}(l), t \\
& M P_{\text {ilpt }} \leq M 1^{*} X_{\text {ilpt }} \quad \forall p, l \in \operatorname{Lp}(p), i \in I l(l), t \\
& M P F_{f l p t} \leq M 2 * Y_{f l p t} \quad \forall p, l \in L p(p), f \in F l(l), t \\
& Z I_{i l p t} \geq X_{i l p t}-X_{i l p t-1} \quad \forall p, l \in L p(p), i \in I l(l), t \\
& \sum_{i} Z I_{i l p t} \geq \sum_{i} X_{i l p t}-1 \quad \forall p, l \in L p(p), t \\
& Z F_{f l p t} \geq Y_{f l p t}-Y_{f l p t-1} \quad \forall p, l \in L p(p), f \in F l(l), t
\end{aligned}
$$




$$
\begin{array}{lc}
\sum_{f} Z F_{f l p t} \geq \sum_{f} Y_{f l p t}-1 & \forall p, l \in L p(p), t \\
\sum_{t=t^{\prime}}^{t^{\prime}+t m f_{f l p}-1} Z F_{f l p t} \leq 1 & \forall p, l \in L p(p), f \in F l(l), t^{\prime}=1, . ., T-t m f_{f l p}+1
\end{array}
$$$$
\sum_{l \in L p(p)}\left(1-c m_{i}\right) * c q_{i} * M P_{i l p t}=\sum_{a \in A p(p)} C T A_{i p a t} \quad \forall p, i \in I p(p), t
$$$$
\sum_{a \in A b(b)} C S C_{i b a t} \geq{\min s c_{i b}} * S_{i b t} \quad \forall i \in P F S P, b \in B i(i), t
$$$$
\sum_{a \in A b(b)} C S C_{i b a t} \geq \min c_{i b} * S_{i b t} \quad \forall i \in P F S T, b \in B i(i), t
$$$$
\sum_{a \in A b(b)} C S C_{i b a t} \leq \operatorname{casc}_{i b t} * S_{i b t} \quad \forall i \in P F S P, b \in B i(i), t
$$$$
\sum_{a \in A b(b)} \operatorname{CSC}_{i b a t} \leq \operatorname{casc}_{i b t} * S_{i b t} \quad \forall i \in \text { PFST }, b \in B i(i), t
$$

$$
\begin{array}{ll}
I N A_{\text {iat }} \geq s s a_{\text {ia }} & \forall a, i \in \operatorname{Ia}(a), t \\
\sum_{i \in \operatorname{Ia}(a)} I N A_{\text {iat }} \leq \text { capal }_{a} & \forall a, t
\end{array}
$$

$I N A_{\text {iat }}=I N A_{\text {iat }-1}+\sum_{p \in P a(a)} C T A_{\text {ipat }}-V E A_{\text {iat }}-\sum_{q \in Q a(a)} C T C L_{\text {iaqt }} \quad \forall i \in P F N S, a, t$

$$
\begin{aligned}
& I N A_{i a t}=I N A_{i a t-1}+\sum_{p \in P a(a)} C T A_{i p a t}+\sum_{b \in B a(a) \wedge b \in B i(i)} C S C_{i b a t}-V E A_{i a t}-\sum_{q \in Q a(a)} C T C L_{i a q t} \quad \forall i \in P F S P, a, t \\
& I N A_{i a t}=I N A_{i a t-1}+\sum_{b \in B a(a) \wedge b \in B i(i)} C S C_{i b a t}-V E A_{i a t}-\sum_{q \in Q a(a)} C T C L_{i a q t} \quad \forall i \in P F S T, a, t \\
& V E A_{i a t}+D I F A_{i a t}-D I F A_{i a t-1}=d a_{i a t} \quad \forall a, i \in I a(a), t \\
& D I F A_{i a t} \leq \alpha 1^{*} d a_{i a t} \quad \forall a, i \in \operatorname{Ia}(a), t \\
& \sum_{a \in A q(q)} C T C L_{\text {iaqt }}=\sum_{w \in W q(q)} C T T K_{i q w t} \quad \forall q, i \in I q(q), t \\
& C T T K_{i q w t}=V E T K_{i w t} \quad \forall w, q \in Q w(w), i \in I w(w), t
\end{aligned}
$$




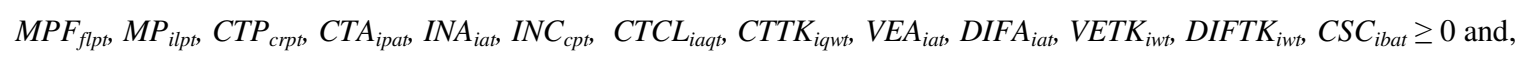

$X_{i l p t}, Y_{f l p t}, Z F_{f l p t}, Z I_{i l p t}, S_{i b t} \in\{0,1\}$

$\forall f \in F, \forall i \in I, \forall c \in C, \forall l \in L, \forall p \in P, \forall a \in A, \forall q \in Q, \forall w \in W, \forall r \in R, \forall b \in B, \forall t \in T$

The objective function (1) expresses the total net profit over the time periods that have been computed by subtracting total costs from total revenues. Total revenue is included in the income produced by sales in central warehouses and shops. Total costs include transport and purchases costs of RMs, production costs of FGs and setup costs of product families and FGs in production plants, the cost of transport from production plants to warehouses, storage costs, backorder costs in warehouses, costs of subcontracting the FG in the warehouses, transport costs from warehouses to logistics centres, and from logistics centres to shops, and, finally, the costs of backorders in shops.

Constraint (2) is the inventory balance equation of the RM required to manufacture various FGs, of which it forms part. Constraint (3) establishes that the RM inventory does not fall below a minimum value assigned by the safety stock that has been established for each RM, so that a lack of supply does not disrupt production. Constraint (4) ensures that the amount of each RM supplied to all the production plants in each time period does not exceed the capacity of the supply available for each supplier of each RM.

Constraint (5) ensures that the capacity required for the setup of product families and articles in each time period, and the processing of the lots assigned to each line, do not exceed the capacity available on each line at each time period. Constraint (6) ensures that the amount to be produced per product family on each production line in each time period equals the sum of the amounts of the articles belonging to each product family to be manufactured on each particular production line. Constraint (7) guarantees that should a certain amount of an article be manufactured on a production line, it is equal to or above the minimum lot size established for the article on that line. Constraints (8) and (9) ensure that only a certain amount of an article or product family could be manufactured on one line, provided that the production of this product or product family, respectively, has been assigned to this line. Parameters M1 and M2 are large enough integer numbers.

Constraints (10)-(14) guarantee the control of the setup of articles and families. Constraint (10) relates the setup variable $\left(Z I_{i \mid p t}\right)$ to the production scheduling variables in the current and previous periods ( $X_{i l p t}$ and $X_{\text {ilpt- } 1}$, respectively). A changeover to product i on line j occurs in period t, and only if $X_{i l p t}=1$ and $X_{i l p t-1}=0$. If the line was inactive in period $\mathrm{t}-1$, and only a certain amount of $\mathrm{i}$ was produced in time period $t$, the model would calculate a setup for this product. If products were produced on the same production line in time periods $t$ and $t-1$, Constraint (11) enables saving a single changeover by consecutively sequencing production of one of them, i.e., it is possible to save a changeover for one of the products if its production on the line was done at the end of time period $\mathrm{t}-1$ and continued to the start of time period t. Constraints (12) and (13) are similar to Constraints (10) and (11), respectively, but refer to product families. Constraint (14) ensures that a production line is setup for a product family at least during the minimum run length of that product family on that particular line $\left(\operatorname{tmf}_{f / p}\right)$.

As this model focuses only on first quality FGs planning, Constraint (15) ensures that part of the non-faulty production of a given FG, which is first quality, is transported to the central warehouses that can be supplied by this plant. 
Constraints (16) and (17) guarantee that the minimum amounts to be subcontracted to external suppliers of partly and completely subcontracted products, respectively, are met should a decision be made to subcontract them during a specific time period. Constraints (18) and (19) indicate that the subcontracting binary variable takes the value of one when a decision is made to subcontract a certain amount of FGs that can be subcontracted partly or completely, respectively. These constraints also ensure that the amount of FGs subcontracted and transported to warehouses, at each time period and for each FG, that can be subcontracted partly and completely, do not exceed the amount that the corresponding FG supplier has available. As it is possible to meet a certain independent demand through warehouses, Constraint (20) maintains a certain amount of safety stock for each FG to meet any demand variability. Constraint (21) is the limitation in the warehouses' capacity that is assumed to be shared by all the FGs.

Constraints (22)-(24) are inventory balance equations corresponding to FGs that cannot be subcontracted, those that are usually subcontracted partly and when applicable, and those that can only be subcontracted. As Constraint (22) indicates, FGs that cannot be subcontracted and that arrive at the warehouses only come from production plants. Constraint (24) shows how the entry of subcontracted FGs only comes from FG suppliers. Finally, Constraint (23) contemplates the entry of those FGs that can be subcontracted partly in the warehouses, from both production plants and FG suppliers.

As backorders are permitted in both central warehouses and shops, sales may not coincide with the demand for a given time period. Backorder quantities are calculated using Constraint (25). Constraint (26) limits the backorder quantities in each period in terms of a percentage of the demand of each time period.

Constraints (27) and (28) are the inflows and outflows of FGs through each logistic centre and shop, respectively. Constraints (29) and (30) are similar to Constraints (25) and (26), but refer to shops.

The model also contemplates non-negativity constraints and the definition of binary variables (31). Finally, some decision variables can be defined as integers, but could change depending on the real-world problem where the model is applied.

The model is easily adapted to cases wherein backorders are not allowed (with a value of zero for both $\alpha_{1}$ in Constraint (25) and $\alpha_{2}$ in Constraint (30), or by omitting the corresponding backorder decision variables), and when inventory in both the production plants and shops may be held. By defining the different sets, the model is capable of not only representing situations in which all the products may be distributed via all the routes, but also those situations in which this product flow is restricted: for instance, cases in which only certain products may be supplied by certain nodes, and/or the limitations with which the nodes supply others. All this can be achieved without having to introduce additional constraints. Although the minimum run lengths for families $\left(\operatorname{tmf}_{f \mid p}\right)$ and minimum lot sizes for manufacturing articles $\left(I m i_{i l p}\right)$ are considered in industry practice, another possible way to extend the model would be to consider minimum lot sizes or run lengths for both.

\section{A detailed computational example}

\subsection{Input data description}

We describe in detail an example to validate the described model. The SC physical configuration, cost data, and SC operation characteristics are inspired by a real SC in the Spanish ceramic sector. The model data are based on historical SC information (demand data) and on the mean real values provided by this SC (times and costs). While the physical configuration has been 
slightly modified for reasons of confidentiality, it respects the structure described in the article. Additionally, we decided to consider an example problem of a size that represents the main relevant sector characteristics, but not excessively large so that it could be described in detail here. Nonetheless, a real industrial problem would be on a larger scale than that considered in this work and would require more data that are beyond the validation purpose of our proposal.

The model's planning horizon is assumed to be six weeks (which is usual in the ceramic sector), but excludes the frozen horizon length (usually two/three weeks). In the example considered, 4 FGs, labelled $i_{1}$ through to $i_{4}$ and $3 \mathrm{FG}$ families, $f_{1}, f_{2}$, and $f_{3}$, were included in such a way that $i_{1}$ and $i_{2}$ belong to $f_{1}, i_{3}$ belongs to $f_{3}$, and $i_{4}$ belongs to $f_{4}$. The FGs, $i_{1}$ and $i_{2}$, have the same format $\left(30^{*} 30\right)$ and are innovative products chosen from the SC catalogue with high added value. They belong to the PFNS set and cannot therefore be subcontracted. The FGs, $i_{3}$ and $i_{4}$, have the same format (20*20). The FG, $i_{3}$, belongs to PFSP, so it may be partly subcontracted. $i_{4}$ belongs to PFST, meaning that it has to be totally subcontracted. Other relevant FGs data for the model can be consulted in Tables 5-8. The FG demand in warehouses $\left(d a_{i a t}\right)$ and shops ( $\left.d t_{\text {iwt }}\right)$ was obtained from the SC historical data, and the sale prices in warehouses $\left(p a_{i a}\right)$ and shops $\left(p w_{i w}\right)$ were provided by the SC. Characteristics of central warehouse customers and shop customers differ greatly. Typical examples of central warehouse customers are independent distributors not belonging to the firm and construction firms; meanwhile, those who intend to do house renovations are typical examples of shop customers.

Three production plants exist, $p_{1}, p_{2}$, and $p_{3}$, with two production lines per plant, so: $l_{1}$ and $I_{2}$ belong to $p_{1}, l_{3}$ and $I_{4}$ belong to $p_{2}$, and $I_{5}$ and $I_{6}$ and belong to $p_{3}$. All the product families may be manufactured on the production lines at the various plants. The production capacity assumed to be available on each line for each time period $\left(c a f_{\text {pt }}\right)$ is $\mathbf{5 0}$ hours. It is usual in the ceramic sector that production lines work on a two-shift basis of 8 hours per shift (80 hours/week). Because our example only deals with the demand of four FGs, which is obviously only one part of the real demand for the time horizon considered, the production line capacity has been reduced to be more realistic.

The SC considers a mean total production cost of $9 € / \mathrm{m}^{2}$ where around $50-60 \%$ corresponds to productive costs (direct labour and energy), excluding setup costs, and where around 50-40\% corresponds to replenishment costs (RMs and corresponding transport costs). This information has been used to obtain the FG productive costs $\left(\operatorname{costp}_{i l}\right)$, as seen in Table 6 . A mean value of an 8hour setup time (tsetupf fip) is assumed for all the product families, while a 4-hour setup time is assumed for all the FGs within their product family (tsetupi $i_{i p}$ ). In the ceramic tile sector, setups are usually carried out by maintenance personnel. The corresponding setup costs (costsetupf $f$, costsetupi $i_{i p}$ ) mainly include the costs of maintenance personnel and the material used for the setup. Table 6 provides the data of the minimum lot size $\left(I m i_{i p}\right)$ and the unit processing time $\left(t_{f a b}\right.$ ipp $)$. The minimum product family run length $\left(\operatorname{tmf}_{f \mid p}\right)$ is three periods for all the families and lines, and the FG unitary inventory holding cost per period (costina $i_{i a}$ ), were set to $€ 0.16$ for i1, €0.14 for i2, €0.1 for i3, and $€ 0.09$ for i4. All these information were obtained from the ceramic SC.

Some of the most common RM of ceramic FGs are glazes and clays. We only consider the RM clay (c1) with a supply cost per kilogram (costtp crp) of $€ 0.24$. The supplier of this RM ( $r 1)$ is able to supply it to any production plant with a total supply capacity $\left(c a_{c r t}\right)$ of 180000 kilograms. A safety stock ( $s s c_{c p}$ ) of 2000 kilograms of $c 1$ is taken into account for each production plant. Each $\mathrm{m}^{2}$ of $F G$, $\mathrm{i} 1$, i2, and i3 will require 12.2, 12.2, and 11.1 kilograms of $c 1\left(v_{i c}\right)$, respectively. There is also an FG supplier (b1) capable of supplying all the products that can be subcontracted (i3 and i4) to all the warehouses up to a limit of $850 \mathrm{~m}^{2}\left(\right.$ casc $\left._{i b t}\right)$. There are two central warehouses (a1, a2) with a storage capacity (capal $a_{\text {) }}$ of $200000 \mathrm{~m}^{2}$, three logistics centres (q1, q2, and q3) and six shops (w1, w2, w3, w4, w5, and w6). A safety stock $\left(s s a_{i a}\right)$ of $2000 \mathrm{~m}^{2}$ for $i_{1}$ and $i_{2}$ and $1600 \mathrm{~m}^{2}$ for $i_{3}$ and $i_{4}$ is contemplated for each warehouse assigned. All the production plants may supply all the products to all the warehouses, and all the warehouses may supply any logistics centre. Nonetheless, each 
logistics centre (q1, q2, and q3) only supplies two shops, i.e., logistics centre q1 supplies shops w1 and w2, logistics centre q2 supplies shops w3 and w4, and logistics centre q3 supplies shops w5 and $w 6$ with any product. Unitary transportation costs for each FG have been calculated based on their corresponding weight and the distance for transport.

The percentage of faults and defects of all the FGs is $10 \%\left(\mathrm{~cm}_{i}\right)$. Likewise, $98 \%$ of the production can be sold as first quality $\left(c q_{i}\right)$. Both percentages are mean values provided by the SC. A cost of $€ 100$ per $\mathrm{m}^{2}$ of $F G$ backorder and the time period in warehouses and shops is also contemplated. All initial inventories have been set to their corresponding safety stock level. Details on the data used are presented in Tables 5-12.

$$
\begin{aligned}
& \text { [Insert Table } 5 \text { about here] } \\
& \text { [Insert Table } 6 \text { about here] } \\
& \text { [Insert Table } 7 \text { about here] } \\
& \text { [Insert Table } 8 \text { about here] } \\
& \text { [Insert Table } 9 \text { about here] } \\
& \text { [Insert Table } 10 \text { about here] } \\
& \text { [Insert Table } 11 \text { about here] } \\
& \text { [Insert Table } 12 \text { about here] }
\end{aligned}
$$

The proposed model has been done in the MPL language, V4.2. The resolution has been carried out with optimisation solver CPLEX 6.6. Finally, the input data and the model solution values were processed with the Microsoft Access database (2007). The experiment was run on a PC with a 2.40 $\mathrm{GHz}$ processor and $4 \mathrm{~GB}$ of RAM.

\subsection{Evaluation of results}

Before evaluating the model, Tables 13-17 show the most representative values of the decision variables that lead to the optimum model solution and used to evaluate the model.

[Insert Table 13 about here]

[Insert Table 14 about here]

[Insert Table 15 about here]

[Insert Table 16 about here]

[Insert Table 17 about here]

It is worth highlighting that the value of the decision variable sales in the optimum solution of the previous example coincides with the demand data because backorders do not exist in either the central warehouses or shops at any time period.

The assessment method used consisted in analysing the MP-RDSINC model operation according to a set of indicators: computational efficiency, level of service, levels of inventory, and 
the total net profits in terms of planning. Evidently, any other parameter that is characteristic of the setting in which the method has been applied could be included as an indicator. In particular, such parameters are of interest for the example, which is the objective of the application. All the four indicators selected are explained in detail as follows:

The computational efficiency parameter measures the computational effort required to solve models. The indicators are: the number of iterations needed by the solver and used to reach the optimum solution, the number of model variables, the number of integers in the model, the number of constraints in the model, the number of non-zero elements in the constraints matrix that the model contains, the density of the constraints matrix that the model contains, and the CPU time required to obtain the model solution.

The level of service parameter, expressed as a percentage, is $100 \%$ when no delay in demand occurs. If a delay in demand occurs, the level of service could be determined for each planning horizon time period as follows:

$$
\text { Level of Service }(\%)=\left(1-\frac{\text { Backorders }}{\text { CummulativeDemand }}\right) \times 100
$$

To evaluate the inventory parameter levels, the total mean amount of the products inventory (FGs and RMs) for all the planning horizon time periods is calculated.

Alternatively, the inventory maintenance costs are considered in the total net profits parameter. These are the sum of all the incomes less the costs generated in each planning horizon time period considered, i.e., the costs incurred by the production plans provided by the model: replenishment costs, inventory maintenance costs, costs involved in backorders, set up costs involved in the production of a product family and FG, fluctuating production costs, and costs of deliveries among the SC nodes.

Table 18 summarises the computational effort of the model. The Iterations column indicates the number of iterations needed to reach an optimum solution. The number of Variables also appears, these being the Integers, Constraints, and Non-zero elements of the constraints matrix that the model contains. In addition, the Density of the matrix appears. The Solution Time column indicates the time taken to reach a solution in seconds.

[Insert Table 18 about here]

A $100 \%$ level of service was achieved with data in the proposed model. Table 19 shows the mean inventory levels of FGs and RM.

[Insert Table 19 about here]

Finally in Table 20, the value of the net profit, incomes, and total costs are shown. Given the simplifications assumed in the example, these results are an approximation of the reality. The real SC scenario includes a wide variety of production mix and other additional costs (for instance, the replenishment costs of other RMs). In our example, the model generated a total net profit of $€$ 368,232.45. The different components of the MP-RDSINC objective function appear in Table 20: the incomes are those produced by sales in the central warehouses and shops, replenishment costs include transport costs, and the purchases of RMs. Production costs are those incurred in manufacturing FGs in plants. Inventory costs are the storage costs throughout the SC. Setup costs include those related to the setup of product families and FGs in production plants. Outsourcing costs represent the costs of subcontracting FGs in the warehouses. Transport costs include FGs distribution costs throughout the SC from production plants to warehouses, from warehouses to logistics centres, and from logistics centres to shops. Finally, backorder costs reflect the SC penalty in case of deferred demands in warehouses and shops. The total net profit is calculated as the difference between incomes and total costs. 
[Insert Table 20 about here]

\section{Conclusions}

This work presents the MILP model that has been developed to solve the master planning problem for the replenishment-production-distribution of SCs in the ceramic sector for the purpose of maximising the total net profit in multi-supplier, multi-plant, multi-type, multi-level distribution centres with a multi-item and multi-period logistic environment. The model contemplated was inspired by an actual case and includes the most relevant characteristics of the ceramic sector, e.g., those related to setups, minimum lot sizes for articles, and minimum product family run lengths, faults, and first quality products. This model also considers the several distribution levels integrated by nodes of various types. This model was validated by a real-world case example, but one on a smaller scale for the purpose of providing details of all the input data and of the solution obtained.

Many firms in the ceramic sector only work with planning overviews based on spreadsheets. However, given the increasing complexity of product catalogues and current market pressure to reduce supply times, more rigorous methods are needed to optimise resources. The model presented here offers advantages, such as better coordination and communication among the various departments and SC nodes to substantially lower replenishment, production, and distribution costs, and to improve customer service. Furthermore, given the dramatic increase of end products, the possibilities for assigning and establishing lots on production lines multiply. Therefore, the expected reduction of production plan costs on production lines stands out as the model establishes the product families and articles and the corresponding amounts produced on each line in an attempt to save changeovers as far as possible, this being an important objective in the ceramic sector. This model may also assist managers in evaluating the financial impact of the modification of certain data, e.g., the capacities of plants and warehouses, minimum manufacturing times of product families, and so on.

It is crucial to highlight that demand uncertainty is a major challenge for the ceramic SC in particular and for SCs in general. In this context, we are currently conducting research on managing uncertainty in parameters such as demand, based on our previous works (Mula et al. 2006, and Mula et al. 2008). However, some customers in the ceramic sector only purchase first quality FGs, while others would accept inferior quality. This involves using the nomenclature of first, second, and third quality. Although the production capacity in our proposed model has been developed to take all the qualities into account, the distribution of only first quality FGs has also been planned. One way of extending the model would be to include all the qualities of the products in the proposed model, which would impact the distribution of these products to customers, and to consider not only cost, but also other service parameters. Another alternative way of extending the model would be to consider uncertainty in relation to product quality. We may again consider a centralised view of the problem, which this study has done, because as the analysis was carried out, work was being done with an SC of a firm that formed part of a group of firms working in a centralised manner. However, it would also be interesting to consider a collaborative view of the model and to compare both views. Finally, another line of research would be to study the collaborative decision-making processes between RM suppliers and the ceramic tile SC presented in this article. 


\section{References}

Alarcón, F., Lario, F.C., Bozá, A., Pérez, D. 2007, Propuesta de marco conceptual para el modelado del proceso de planificación colaborativa de operaciones en contextos de redes de suministro/distribución (RdS/D), International Conference on Industrial Engineering \& Industrial Management, Madrid, Spain, pp. 873-882.

Alemany, M.M.E., Alarcón, F., Ortiz, A., Lario, F.-C., 2008, Order promising process for extended collaborative selling chain, Production Planning and Control, 19 (2), 105-131.

Bhatnagar, R., Chandra, P., Goyal, S.K., 1993, Models for multi-plant coordination, European Journal of Operational Research, 67, 141-160.

Bilgen, B., Ozkarahan, I., 2007, A mixed-integer linear programming model for bulk grain blending and shipping. International Journal of Production Economics, 107, 555-571.

Boza, A., Alarcón, F., Vicens, E., Alemany, M.M.E., 2007, Propuesta de marco conceptual para el modelado del proceso de planificación colaborativa de una red de suministro/distribución (RdS/D). Visión Informacional, International Conference on Industrial Engineering \& Industrial Management, Madrid, Spain, pp. 883-892.

Ekşioğlu , S.D., Ekşioğlu , B., Romeijn, H.E., 2007, A Lagrangean heuristic for integrated production and transportation planning problems in a dynamic, multi-item, two-layer supply chain. IIE Transactions 39, 191-201.

Ekşioğlu , S.D., Romeijn, H.E., Pardalos, P.M., 2006, Cross-facility management of production and transportation planning problem. Computers and Operations Research, 33, 3231-3251.

Erengüc, S., Simpson, N., Vakharia, A., 1999, Integrated production-distribution planning in supply chains: and invited review. European Journal of Operational Research, 115, 219-236.

Escudero L., Galindo A., García G., Gómez E., Sabau V., 1999, Schumann, a modeling framework for supply chain management under uncertainty, European Journal of Operational Research, 119, 14-34.

Jayaraman V., Pirkul H., 2001, Planning and coordination of production and distribution facilities for multiples commodities, European Journal of Operations Research, 133, 394-408.

Kreipl, S., Pinedo, M., 2004, Planning and scheduling in supply chains: An overview of issues in practice, Production and Operations Management, 13 (1) 77-92.

Lavoie, C., Abdul-Nour, 2003, SME, networking and supply chain improvement, 32nd International conference on computers and Industrial Engineering. Limerick, Ireland.

Liberatore, M.J., Miller T., 1985, A hierarchical production planning system, Interfaces 15, 1-11. 
Lim, S.J., Jeong, S.J., Kim, K.S., Park, M.W., 2006, A simulation approach for productiondistribution planning with consideration given to replenishment policies, International Journal of Advanced Manufacturing Technology 27, 593-603.

Lin, J., Chen , Y., 2004, A supply network planning problem in a multi-stage and multi-site environment. 35th International Conference on Computers and Industrial Engineering.

Meijboom, B., Obel, B., 2007, Tactical coordination in a multi-location and multi-stage operations structure: A model and a pharmaceutical company case. Omega-International Journal of Management Science 35, 258-273.

Mula, J., Poler, R., Garcia, J.P., Lario, F.C., 2006, Models for production planning under uncertainty: A review, International Journal of Production Economics 103, 271-285.

Mula, J., Poler, R., Garcia-Sabater, J.P., 2008, Capacity and material requirement planning modelling by comparing deterministic and fuzzy models, International Journal of Production Research 46, 5589-5606.

Oh, H.C., Karimi, I.A., 2006, Global multiproduct production-distribution planning with duty drawbacks. Aiche Journal 52, 595-610.

Özdamar, L., Birbil, S.I., 1998, Hybrid Heuristics for the capacitated lot sizing and loading problem with setup times and overtime decisions, European Journal of Operational Research 110, 525-547.

Özdamar, L., Birbil, S.I., 1999, A hierarchical planning system for energy intensive production environments, International Journal of Production Economics 58, 115-129.

Özdamar, L., Bozyel, A., 1998, Simultaneous lot sizing and loading of product families on parallel facilities of different classes, International Journal of Production Research 36 (5) 1305-1324.

Park, Y.B., 2005, An integrated approach for production and distribution planning in supply chain management, International Journal of Production Research 43 (6) 1205-1224.

Peidro, D., Mula, J., Poler, R., 2007, Supply chain planning under uncertainty: a fuzzy linear programming approach, Proceedings for the 2007 IEEE International Conference on Fuzzy Systems, London, United Kingdom, pp. 1143-1148.

Pérez, D., Alemany, M.M.E., Vicens, E., Lario, F.C., 2007, Propuesta de marco conceptual para el modelado de la visión decisional del proceso de planificación colaborativa de una red de suministro/distribución (RdS/D), International Conference on Industrial Engineering \& Industrial Management, Madrid, Spain, pp. 893-902

Schulz, E., Diaz, M., Bandoni, J., 2005, Supply chain optimization of large-scale continuous processes, Computers and Chemical Engineering 29, 1305-1316.

Spitter, J.M., Hurkens, C.A.J., de Kok, A.G., Lenstra, J.K., Negenman, E.G., 2005, Linear programming models with planned lead times for supply chain operations planning, European Journal of Operational Research,163, 706-720.

http://mc.manuscriptcentral.com/tprs Email: ijpr@lboro.ac.uk 
Timpe, C.H., Kallrath, J., 2000, Optimal planning in large multisite production networks. European Journal of Operational Research 126, 422-435.

Thomas, D.J., Griffinn, P.M., 1996, Coordinated supply chain management, European Journal of Operational Research 94, 1-15.

Vicens E., Alemany, M.M.E., Andrés, C., Guarch, J.J., 2001, A design and application methodology for hierarchical planning decision support systems in an enterprise integration context. International Journal of Production Economics 74/1-3, 5-20. von Lanzenauer, Ch., Pilz-Glombik, H.K., 2002, Coordinating supply chain decisions: an optimization model. OR Spectrum 24 (1), 59-78.

Wu, D., Golbasi, H., 2004, Multi-item, multi-facility supply chain planning: models, complexities, and algorithm, Computational Optimization and Applications 28, 325-356.

http://mc.manuscriptcentral.com/tprs Email: ijpr@lboro.ac.uk 
Table 1. Indices.

Table 2. Sets of Indices

\begin{tabular}{|c|c|c|c|}
\hline \multicolumn{4}{|c|}{ Sets of Indices } \\
\hline$I l(l)$ & $\begin{array}{l}\text { Set of FGs that can be manufactured on } \\
\text { manufacturing line } l\end{array}$ & $\operatorname{Lp}(p)$ & $\begin{array}{l}\text { Set of manufacturing lines that belong to } \\
\text { production plant } p\end{array}$ \\
\hline$F l(l)$ & $\begin{array}{l}\text { Set of product families that can be manufactured } \\
\text { on manufacturing line } l\end{array}$ & $P a(a)$ & $\begin{array}{l}\text { Set of production plants that can send FGs to } \\
\text { warehouse } a\end{array}$ \\
\hline$I f(f)$ & Set of FGs that belong to product family $f$ & $A q(q)$ & $\begin{array}{l}\text { Set of warehouses that can supply logistics centre } \\
q\end{array}$ \\
\hline $\operatorname{Ip}(p)$ & $\begin{array}{l}\text { Set of FGs that can be produced in production } \\
\text { plant } p\end{array}$ & $R c(c)$ & Set of suppliers that can supply $\mathrm{RM} c$ \\
\hline $\operatorname{Ia}(a)$ & Set of FGs that can be stored in warehouse $a$ & $R p(p)$ & $\begin{array}{l}\text { Set of suppliers of RMs that can supply } \\
\text { production plant } p\end{array}$ \\
\hline$I c(c)$ & Set of FGs of that RM $c$ form part & $C r(r)$ & Set of RMs that can be supplied by supplier $r$ \\
\hline PFNS & Set of FGs that cannot be subcontracted & $Q a(a)$ & $\begin{array}{l}\text { Set of logistics centres that can be supplied by } \\
\text { warehouse } a\end{array}$ \\
\hline PFSP & $\begin{array}{l}\text { Set of FGs that can be subcontracted either } \\
\text { partially or completely }\end{array}$ & $W q(q)$ & $\begin{array}{l}\text { Set of shops that can be supplied by logistics } \\
\text { centres } q\end{array}$ \\
\hline PFST & $\begin{array}{l}\text { Set of FGs that are compulsorily subcontracted } \\
\text { completely }\end{array}$ & $Q w(w)$ & $\begin{array}{l}\text { Set of logistics centres capable of supplying shop } \\
w\end{array}$ \\
\hline $\operatorname{Iq}(q)$ & Set of FGs that can be sent to logistics centre $q$ & $B i(i)$ & $\begin{array}{l}\text { Set of suppliers of FGs } i \text { to which the FG may be } \\
\text { subcontracted }\end{array}$ \\
\hline$I w(w)$ & Set of FGs that can be sent to shop $w$ & $B a(a)$ & $\begin{array}{l}\text { Set of suppliers of FGs that can supply warehouse } \\
a\end{array}$ \\
\hline$L f(f)$ & $\begin{array}{l}\text { Set of manufacturing lines that may produce } \\
\text { product family } f\end{array}$ & $A b(b)$ & $\begin{array}{l}\text { Set of warehouses that can be supplied by the } \\
\text { supplier } b \text { of FGs }\end{array}$ \\
\hline
\end{tabular}


Table 3. Model parameters

\begin{tabular}{|c|c|c|c|}
\hline \multicolumn{4}{|c|}{ Model Parameters } \\
\hline$c a_{c r t}$ & $\begin{array}{l}\text { Capacity (units) of supplying RM } c \text { of } \\
\text { supplier } r \text { in period } t\end{array}$ & $M 1, M 2$ & Very large integers \\
\hline $\operatorname{costtp}_{c r p}$ & $\begin{array}{l}\text { Cost of purchase and transport of one unit } \\
\text { of RM } c \text { from supplier } r \text { to production plant } \\
p\end{array}$ & capal $_{a}$ & Storage capacity $\left(\mathrm{m}^{2}\right)$ in warehouse $a$ \\
\hline$c a f_{l p t}$ & $\begin{array}{l}\text { Production capacity available (time) of } \\
\text { production line } l \text { at plant } p \text { during time } \\
\text { period } t\end{array}$ & $\operatorname{costtcl}_{i a q}$ & $\begin{array}{l}\text { Cost of transporting one } \mathrm{m}^{2} \text { of FG } i \text { from } \\
\text { warehouse } a \text { to logistics centre } q\end{array}$ \\
\hline $\mathrm{cm}_{i}$ & $\begin{array}{l}\text { Loss ratio of } \mathrm{FG} i \text {. It represents the } \\
\text { percentage of faulty } \mathrm{m}^{2} \text { obtained due to the } \\
\text { intrinsic characteristics of the production } \\
\text { process in the ceramics sector. }\end{array}$ & $\operatorname{costina~}_{i a}$ & $\begin{array}{l}\text { Cost of making an inventory of one } \mathrm{m}^{2} \text { of } \\
\text { FG } i \text { in the warehouse during a time period }\end{array}$ \\
\hline$c q_{i}$ & $\begin{array}{l}\text { First quality coefficient of } \mathrm{FG} i \text {. It } \\
\text { represents the percentage of } \mathrm{m}^{2} \text { that can be } \\
\text { sold as first quality. }\end{array}$ & costdifa $_{i a}$ & $\begin{array}{l}\text { Cost of backordering one } \mathrm{m}^{2} \text { of demand of } \\
\text { FG } i \text { in warehouse } a \text { in a time period }\end{array}$ \\
\hline $\operatorname{costta}_{\text {ipa }}$ & $\begin{array}{l}\text { Cost of transporting one } \mathrm{m}^{2} \text { of } \mathrm{FG} i \text { from } \\
\text { production plant } p \text { to warehouse } a\end{array}$ & $p a_{i a}$ & $\begin{array}{l}\text { Sales value of one } \mathrm{m}^{2} \text { of } \mathrm{FG} i \text { in warehouse } \\
a\end{array}$ \\
\hline $\operatorname{costp}_{i l p}$ & $\begin{array}{l}\text { Cost of producing one } \mathrm{m}^{2} \text { of } \mathrm{FG} i \text { on } \\
\text { production line } l \text { of production plant } p\end{array}$ & $d a_{\text {iat }}$ & $\begin{array}{l}\text { External demand }\left(\mathrm{m}^{2}\right) \text { of } \mathrm{FG} i \text { at the } \\
\text { warehouse } a \text { in period } t\end{array}$ \\
\hline costsetupf flp & $\begin{array}{l}\text { Setup costs for product family } f \text { on } \\
\text { production line } l \text { of production plant } p\end{array}$ & $s s a_{i a}$ & Safety stock $\left(\mathrm{m}^{2}\right)$ of FG $i$ at warehouse $a$ \\
\hline costsetup ilp & $\begin{array}{l}\text { Setup costs for FG } i \text { on production line } l \text { of } \\
\text { production plant } p\end{array}$ & $\alpha 1$ & $\begin{array}{l}\text { Maximum backorder quantity permitted in } \\
\text { a period in warehouses expressed as a } \\
\text { percentage of the demand of that period }\end{array}$ \\
\hline$t f a b_{i l p}$ & $\begin{array}{l}\text { Time to process one } \mathrm{m}^{2} \text { of } \mathrm{FG} i \text { on } \\
\text { production line } l \text { of production plant } p\end{array}$ & $\operatorname{costsc}_{i b}$ & $\begin{array}{l}\text { Cost of subcontracting one } \mathrm{m}^{2} \text { of } \mathrm{FG} i \text { to } \\
\text { FG supplier } b\end{array}$ \\
\hline$t_{\text {setupf } f t p}$ & $\begin{array}{l}\text { Setup time for product family } f \text { on } \\
\text { production line } l \text { of production plant } p\end{array}$ & $\operatorname{minsc}_{i b}$ & $\begin{array}{l}\text { Minimum amount }\left(\mathrm{m}^{2}\right) \text { of } \mathrm{FG} i \text { to be } \\
\text { subcontracted to FG supplier } b\end{array}$ \\
\hline tsetupi $_{i p}$ & $\begin{array}{l}\text { Setup time for article } i \text { on production line } l \\
\text { of production plant } p\end{array}$ & $\operatorname{costttk}_{i q w}$ & $\begin{array}{l}\text { Cost to transport one } \mathrm{m}^{2} \text { of } \mathrm{FG} i \text { from } \\
\text { logistics centre } q \text { to shop } w\end{array}$ \\
\hline $\operatorname{lmi} i_{i p}$ & $\begin{array}{l}\text { Minimum lot size }\left(\mathrm{m}^{2}\right) \text { of } \mathrm{FG} i \text { on } \\
\text { production line } l \text { of production plant } p\end{array}$ & costdiftk $_{i w}$ & $\begin{array}{l}\text { Cost to backorder one } \mathrm{m}^{2} \text { of the demand of } \\
\text { FG } i \text { in a time period at shop } w\end{array}$ \\
\hline $\operatorname{tmf} f l p$ & $\begin{array}{l}\text { Minimum run length (expressed as } \\
\text { multiples of the time period used) of } \\
\text { product family } f \text { on production line } l \text { of } \\
\text { production plant } p\end{array}$ & $p w_{i w}$ & Sales price of one $\mathrm{m}^{2}$ of FG $i$ in shop $w$ \\
\hline$v_{i c}$ & $\begin{array}{l}\text { Units of RM } c \text { needed to produce one } \mathrm{m}^{2} \text { of } \\
\text { FG } i\end{array}$ & $d t k_{i w t}$ & $\begin{array}{l}\text { External demand }\left(\mathrm{m}^{2}\right) \text { of } \mathrm{FG} i \text { in shop } w \\
\text { during the time period } t\end{array}$ \\
\hline \multirow[t]{2}{*}{$s s c_{c p}$} & Safety stock of RM $c$ in production plant $p$ & $\alpha 2$ & $\begin{array}{l}\text { Maximum backorder quantity permitted in } \\
\text { a period in shops expressed as a percentage } \\
\text { of the demand of that period }\end{array}$ \\
\hline & & $\operatorname{casc}_{i b t}$ & $\begin{array}{l}\text { Supply capacity }\left(\mathrm{m}^{2}\right) \text { of } \mathrm{FG} i \text { of supplier } b \\
\text { in time period } t\end{array}$ \\
\hline
\end{tabular}


Table 5. Data of FG in warehouses

\begin{tabular}{|c|c|c|c|c|c|c|c|c|c|c|c|}
\hline \multirow[b]{2}{*}{ Family } & \multirow[b]{2}{*}{$\mathrm{FG}$} & \multirow[b]{2}{*}{ Warehouse } & \multicolumn{6}{|c|}{ daiat } & \multirow[b]{2}{*}{ costinia } & \multirow[b]{2}{*}{ costdifia } & \multirow[b]{2}{*}{ paia } \\
\hline & & & t1 & t2 & t3 & t4 & t5 & t6 & & & \\
\hline \multirow[t]{4}{*}{$f_{1}$} & $\mathrm{i}_{1}$ & $a_{1}$ & 1011 & 1264 & 1516 & 1264 & 627 & 783 & 0,16 & 100 & 17,86 \\
\hline & & a2 & 544 & 680 & 816 & 680 & 337 & 1200 & 0,16 & 100 & 17,86 \\
\hline & i2 & $\mathrm{a}_{1}$ & 1524 & 1906 & 2287 & 1906 & 1021 & 1277 & 0,14 & 100 & 15,74 \\
\hline & & $a_{2}$ & 1863 & 2329 & 2795 & 2329 & 1248 & 1560 & 0,14 & 100 & 15,74 \\
\hline \multirow[t]{2}{*}{$\mathrm{f}_{2}$} & i3 & $a_{1}$ & 443 & 554 & 664 & 554 & 242 & 303 & 0,10 & 100 & 11,65 \\
\hline & & a2 & 823 & 1028 & 1234 & 1028 & 450 & 1300 & 0,10 & 100 & 11,65 \\
\hline \multirow[t]{2}{*}{$f_{3}$} & \multirow[t]{2}{*}{$\mathrm{i}_{4}$} & $a_{1}$ & 229 & 286 & 343 & 286 & 121 & 152 & 0,09 & 100 & 9,73 \\
\hline & & $a_{2}$ & 187 & 234 & 280 & 234 & 99 & 124 & 0,09 & 100 & 9,73 \\
\hline
\end{tabular}

Table 4. Decision Variables

\begin{tabular}{|c|c|c|c|}
\hline \multicolumn{4}{|c|}{ Decision Variables } \\
\hline$C T P_{c r p t}$ & $\begin{array}{l}\text { Amount of RM } c \text { to be purchased and transported } \\
\text { from supplier } r \text { to production plant } p \text { in time } \\
\text { period } t\end{array}$ & $I N A_{\text {iat }}$ & $\begin{array}{l}\text { Inventory }\left(\mathrm{m}^{2}\right) \text { of FG } i \text { in warehouse } a \text { in time } \\
\text { period } t\end{array}$ \\
\hline$I N C_{c p t}$ & $\begin{array}{l}\text { Inventory of the RM } c \text { at plant } p \text { at the end of } \\
\text { time period } t\end{array}$ & $C S C_{i b a t}$ & $\begin{array}{l}\text { Amount }\left(\mathrm{m}^{2}\right) \text { of } \mathrm{FG} i \text { subcontracted to } \\
\text { supplier } b \text { for warehouse } a \text { in time period } t\end{array}$ \\
\hline$M P F_{f l p t}$ & $\begin{array}{l}\text { Amount }\left(\mathrm{m}^{2}\right) \text { of product family } f \text { manufactured } \\
\text { on production line } l \text { of production plant } p \text { in time } \\
\text { period } t\end{array}$ & $S_{i b t}$ & $\begin{array}{l}\text { Binary variable with a value of } 1 \text { if FG } i \text { is } \\
\text { subcontracted to supplier } b \text { in time period } t\end{array}$ \\
\hline$M P_{i l p t}$ & $\begin{array}{l}\text { Amount }\left(\mathrm{m}^{2}\right) \text { of } \mathrm{FG} i \text { manufactured on } \\
\text { production line } l \text { of production plant } p \text { in time } \\
\text { period } t\end{array}$ & $V E A_{\text {iat }}$ & $\begin{array}{l}\text { Amount }\left(\mathrm{m}^{2}\right) \text { of FG } i \text { sold in warehouse } a \\
\text { during time period } t\end{array}$ \\
\hline$X_{i l p t}$ & $\begin{array}{l}\text { Binary variable with a value of } 1 \text { if } \mathrm{FG} i \text { is } \\
\text { manufactured on production line } l \text { of production } \\
\text { plant } p \text { in time period } t \text {, and with a value of } 0 \\
\text { otherwise }\end{array}$ & $D I F A_{\text {iat }}$ & $\begin{array}{l}\text { Backorder quantity }\left(\mathrm{m}^{2}\right) \text { of } \mathrm{FG} i \text { in warehouse } \\
a \text { during time period } t\end{array}$ \\
\hline$Y_{f l p t}$ & $\begin{array}{l}\text { Binary variable with a value of } 1 \text { if product } \\
\text { family } f \text { is manufactured on production line } l \text { of } \\
\text { production plant } p \text { in time period } t \text {, and with a } \\
\text { value } 0 \text { otherwise }\end{array}$ & $C T C L_{\text {iaqt }}$ & $\begin{array}{l}\text { Amount }\left(\mathrm{m}^{2}\right) \text { of } \mathrm{FG} i \text { transported from } \\
\text { warehouse } a \text { to logistics centre } q \text { in time } \\
\text { period } t\end{array}$ \\
\hline$Z I_{i l p t}$ & $\begin{array}{l}\text { Binary variable with a value of } 1 \text { if a setup takes } \\
\text { place of product } i \text { on production line } l \text { of } \\
\text { production plant } p \text { in time period } t \text {, and with a } \\
\text { value of } 0 \text { otherwise }\end{array}$ & CTTK $_{\text {iqwt }}$ & $\begin{array}{l}\text { Amount }\left(\mathrm{m}^{2}\right) \text { of } \mathrm{FG} i \text { transported from } \\
\text { logistics centre } q \text { to shop } w \text { in time period } t\end{array}$ \\
\hline$Z F_{f l p t}$ & $\begin{array}{l}\text { Binary variable with a value of } 1 \text { if a setup takes } \\
\text { place of product family } f \text { on production line } l \text { of } \\
\text { production plant } p \text { in time period } t \text {, and with a } \\
\text { value of } 0 \text { otherwise }\end{array}$ & $V E T K_{i w t}$ & $\begin{array}{l}\text { Amount }\left(\mathrm{m}^{2}\right) \text { of FG } i \text { sold in shop } w \text { during } \\
\text { time period } t\end{array}$ \\
\hline$C T A_{\text {ipat }}$ & $\begin{array}{l}\text { Amount }\left(\mathrm{m}^{2}\right) \text { of } \mathrm{FG} i \text { to be transported from } \\
\text { production plant } p \text { to warehouse } a \text { in time period } \\
t\end{array}$ & DIF & $\begin{array}{l}\text { Backorder quantity }\left(\mathrm{m}^{2}\right) \text { of FG } i \text { in shop } w \\
\text { during time period } t\end{array}$ \\
\hline
\end{tabular}


Table 6. Data of FG in plants

\begin{tabular}{|c|c|c|c|c|c|c|c|c|}
\hline Family & $\mathrm{FG}$ & Line & Plant & costpilp & costsetupilp & tfabilp & Imilip & costsetupfflp \\
\hline \multirow[t]{12}{*}{$f_{1}$} & \multirow[t]{6}{*}{$\mathrm{i}_{1}$} & $I_{1}$ & $\mathrm{p}_{1}$ & 5,76 & 459,43 & 0,021 & 1500 & 930,46 \\
\hline & & $\mathrm{I}_{2}$ & $p_{1}$ & 5,76 & 459,43 & 0,019 & 1500 & 930,46 \\
\hline & & 13 & $\mathrm{p}_{2}$ & 5,76 & 459,43 & 0,019 & 1500 & 930,46 \\
\hline & & 14 & $\mathrm{p}_{2}$ & 5,76 & 459,43 & 0,021 & 1500 & 930,46 \\
\hline & & 15 & $\mathrm{p}_{3}$ & 5,76 & 459,43 & 0,019 & 1500 & 930,46 \\
\hline & & 16 & $\mathrm{p}_{3}$ & 5,76 & 459,43 & 0,019 & 1500 & 930,46 \\
\hline & \multirow[t]{6}{*}{$i_{2}$} & $I_{1}$ & $p_{1}$ & 5,28 & 351,16 & 0,015 & 1500 & 930,46 \\
\hline & & $\mathrm{I}_{2}$ & $p_{1}$ & 5,28 & 351,16 & 0,017 & 1500 & 930,46 \\
\hline & & 13 & $\mathrm{p}_{2}$ & 5,28 & 351,16 & 0,017 & 1500 & 930,46 \\
\hline & & $I_{4}$ & $\mathrm{p}_{2}$ & 5,28 & 351,16 & 0,017 & 1500 & 930,46 \\
\hline & & 15 & $\mathrm{p}_{3}$ & 5,28 & 351,16 & 0,015 & 1500 & 930,46 \\
\hline & & 16 & $\mathrm{p}_{3}$ & 5,28 & 351,16 & 0,015 & 1500 & 930,46 \\
\hline \multirow[t]{6}{*}{$f_{2}$} & \multirow[t]{6}{*}{ iз } & $I_{1}$ & $\mathrm{p}_{1}$ & 4,8 & 322,29 & 0,014 & 1500 & 798,32 \\
\hline & & $\mathrm{I}_{2}$ & $p_{1}$ & 4,8 & 322,29 & 0,012 & 1500 & 798,32 \\
\hline & & $I_{3}$ & $\mathrm{p}_{2}$ & 4,8 & 322,29 & 0,014 & 1500 & 798,32 \\
\hline & & $1_{4}$ & $\mathrm{p}_{2}$ & 4,8 & 322,29 & 0,014 & 1500 & 798,32 \\
\hline & & 15 & $\mathrm{p}_{3}$ & 4,8 & 322,29 & 0,012 & 1500 & 798,32 \\
\hline & & 16 & $\mathrm{p}_{3}$ & 4,8 & 322,29 & 0,014 & 1500 & 798,32 \\
\hline
\end{tabular}
( ( ( (5)

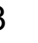
. 
Table 7. Data of FG in shops

\begin{tabular}{|c|c|c|c|c|c|c|c|c|}
\hline \multirow[b]{2}{*}{$F G$} & \multirow[b]{2}{*}{ Shop } & \multirow[b]{2}{*}{ p $W_{\text {iw }}$} & \multicolumn{5}{|c|}{ dtkiwt } & \multirow[b]{2}{*}{ t6 } \\
\hline & & & $\mathrm{t}_{1}$ & t2 & $t_{3}$ & $\mathrm{t}_{4}$ & t5 & \\
\hline \multirow[t]{6}{*}{$\mathrm{i}_{1}$} & $\mathrm{~W}_{1}$ & 20,54 & 87 & 109 & 131 & 115 & 82 & 103 \\
\hline & $w_{2}$ & 20,54 & 124 & 155 & 185 & 167 & 116 & 146 \\
\hline & $w_{3}$ & 20,54 & 160 & 200 & 240 & 212 & 151 & 188 \\
\hline & $W_{4}$ & 20,54 & 95 & 118 & 142 & 124 & 89 & 111 \\
\hline & $\mathrm{W}_{5}$ & 20,54 & 109 & 136 & 164 & 147 & 103 & 128 \\
\hline & $\mathrm{W}_{6}$ & 20,54 & 153 & 191 & 229 & 202 & 144 & 180 \\
\hline \multirow[t]{6}{*}{$\mathrm{i}_{2}$} & $\mathrm{w}_{1}$ & 18,11 & 116 & 145 & 174 & 154 & 109 & 136 \\
\hline & $\mathrm{w}_{2}$ & 18,11 & 170 & 212 & 255 & 225 & 160 & 200 \\
\hline & $w_{3}$ & 18,11 & 131 & 164 & 197 & 172 & 124 & 154 \\
\hline & $\mathrm{W}_{4}$ & 18,11 & 162 & 203 & 243 & 216 & 153 & 191 \\
\hline & W5 & 18,11 & 100 & 125 & 151 & 132 & 94 & 118 \\
\hline & $\mathrm{w}_{6}$ & 18,11 & 93 & 116 & 139 & 129 & 87 & 109 \\
\hline \multirow[t]{6}{*}{ is } & $w_{1}$ & 13,4 & 321 & 401 & 482 & 413 & 457 & 572 \\
\hline & $w_{2}$ & 13,4 & 190 & 237 & 285 & 241 & 270 & 338 \\
\hline & $w_{3}$ & 13,4 & 219 & 274 & 328 & 283 & 312 & 390 \\
\hline & $W_{4}$ & 13,4 & 248 & 327 & 372 & 310 & 353 & 442 \\
\hline & $W_{5}$ & 13,4 & 306 & 383 & 460 & 396 & 436 & 546 \\
\hline & $\mathrm{w}_{6}$ & 13,4 & 175 & 219 & 263 & 228 & 249 & 312 \\
\hline \multirow[t]{6}{*}{$\mathrm{i}_{4}$} & $w_{1}$ & 11,2 & 20 & 25 & 30 & 34 & 75 & 94 \\
\hline & $w_{2}$ & 11,2 & 29 & 36 & 43 & 49 & 106 & 133 \\
\hline & $\mathrm{w}_{3}$ & 11,2 & 25 & 31 & 38 & 42 & 94 & 117 \\
\hline & $\mathrm{W}_{4}$ & 11,2 & 25 & 31 & 38 & 39 & 94 & 117 \\
\hline & $w_{5}$ & 11,2 & 35 & 44 & 53 & 57 & 131 & 164 \\
\hline & $\mathrm{w}_{6}$ & 11,2 & 37 & 46 & 55 & 61 & 138 & 172 \\
\hline
\end{tabular}

Table 8. Data of FG in suppliers

\begin{tabular}{|c|c|c|c|}
\hline $\mathrm{FG}$ & Supplier & costscib & minscib \\
\hline $\mathrm{i}_{3}$ & $\mathrm{~b}_{1}$ & 10 & 100 \\
\hline $\mathrm{i}_{4}$ & $\mathrm{~b}_{1}$ & 7,1 & 100 \\
\hline
\end{tabular}


Table 9. FG transport costs (1)

\begin{tabular}{|c|c|c|c|}
\hline $\mathrm{FG}$ & Plant & Warehouse & costtaipa \\
\hline \multirow[t]{6}{*}{$i_{1}$} & \multirow[t]{2}{*}{$p_{1}$} & $a_{1}$ & 0,054 \\
\hline & & $a_{2}$ & 0,05 \\
\hline & \multirow[t]{2}{*}{$\mathrm{p}_{2}$} & $a_{1}$ & 0,05 \\
\hline & & $\mathrm{a}_{2}$ & 0,054 \\
\hline & \multirow[t]{2}{*}{$p_{3}$} & $a_{1}$ & 0,088 \\
\hline & & $\mathrm{a}_{2}$ & 0,08 \\
\hline \multirow[t]{6}{*}{ i2 } & \multirow{2}{*}{$\overline{p_{1}}$} & $a_{1}$ & 0,054 \\
\hline & & $\mathrm{a}_{2}$ & 0,05 \\
\hline & \multirow[t]{2}{*}{$p_{2}$} & $a_{1}$ & 0,05 \\
\hline & & $a_{2}$ & 0,054 \\
\hline & \multirow[t]{2}{*}{$p_{3}$} & $a_{1}$ & 0,088 \\
\hline & & $a_{2}$ & 0,08 \\
\hline \multirow[t]{6}{*}{ i 3} & \multirow[t]{2}{*}{$\mathrm{p}_{1}$} & $a_{1}$ & 0,054 \\
\hline & & $a_{2}$ & 0,05 \\
\hline & \multirow[t]{2}{*}{ p2 } & $a_{1}$ & 0,05 \\
\hline & & $a_{2}$ & 0,054 \\
\hline & \multirow[t]{2}{*}{ p3 } & $a_{1}$ & 0,088 \\
\hline & & $\mathrm{a}_{2}$ & 0,08 \\
\hline
\end{tabular}

Table 10. FG transport costs (2)

\begin{tabular}{|c|c|c|c|c|c|c|c|}
\hline $\mathrm{FG}$ & Warehouse & Logistics Centre & costtcliaq & $F G$ & Warehouse & Logistics Centre & costtcliaq \\
\hline \multirow[t]{6}{*}{$\mathrm{i}_{1}$} & \multirow[t]{3}{*}{$\mathrm{a}_{1}$} & $q_{1}$ & 0,305 & \multirow[t]{6}{*}{ iз } & \multirow[t]{3}{*}{$a_{1}$} & $q_{1}$ & 0,77 \\
\hline & & $\mathrm{q}_{2}$ & 1,06 & & & $\mathrm{q}_{2}$ & 2,7 \\
\hline & & $q_{3}$ & 1,24 & & & $q_{3}$ & 3,15 \\
\hline & \multirow[t]{3}{*}{ a2 } & $\mathrm{q}_{1}$ & 0,305 & & \multirow[t]{3}{*}{$a_{2}$} & $\mathrm{q}_{1}$ & 0,77 \\
\hline & & $q_{2}$ & 1,06 & & & $\mathrm{q}_{2}$ & 2,7 \\
\hline & & $q_{3}$ & 1,24 & & & $q_{3}$ & 3,15 \\
\hline \multirow[t]{6}{*}{$\mathrm{i}_{2}$} & \multirow[t]{3}{*}{$a_{1}$} & $q_{1}$ & 0,305 & \multirow[t]{6}{*}{$\mathrm{i}_{4}$} & \multirow[t]{3}{*}{$a_{1}$} & $q_{1}$ & 0,77 \\
\hline & & $q_{2}$ & 1,06 & & & $\mathrm{q}_{2}$ & 2,7 \\
\hline & & $q_{3}$ & 1,24 & & & 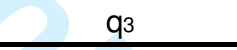 & 3,15 \\
\hline & \multirow[t]{3}{*}{ a2 } & $q_{1}$ & 0,305 & & \multirow[t]{3}{*}{$\mathrm{a}_{2}$} & 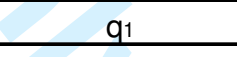 & 0,77 \\
\hline & & $\mathrm{q}_{2}$ & 1,06 & & & $\mathrm{q}_{2}$ & 2,7 \\
\hline & & $q_{3}$ & 1,24 & & & $q_{3}$ & 3,15 \\
\hline
\end{tabular}


Table 11. FG transport costs (3)

\begin{tabular}{|c|c|c|c|c|c|c|c|}
\hline $\mathrm{FG}$ & Logistics Centre & Shop & costttkiqw & FG & Logistics Centre & Shop & costttkiqw \\
\hline \multirow[t]{6}{*}{$\mathrm{i}_{1}$} & \multirow[t]{2}{*}{$\mathbf{q}_{1}$} & $\mathrm{~W}_{1}$ & 0,081 & \multirow[t]{6}{*}{ із } & \multirow[t]{2}{*}{$q_{1}$} & $w_{1}$ & 0,206 \\
\hline & & $\mathrm{W}_{2}$ & 0,09 & & & $w_{2}$ & 0,229 \\
\hline & \multirow[t]{2}{*}{$q_{2}$} & $w_{3}$ & 0,072 & & \multirow[t]{2}{*}{$q_{2}$} & $w_{3}$ & 0,183 \\
\hline & & $\mathrm{W}_{4}$ & 0,081 & & & $\mathrm{~W} 4$ & 0,206 \\
\hline & \multirow[t]{2}{*}{$q_{3}$} & W5 & 0,068 & & \multirow[t]{2}{*}{$q_{3}$} & $\mathrm{~W}_{5}$ & 0,172 \\
\hline & & W6 & 0,09 & & & W6 & 0,229 \\
\hline \multirow[t]{6}{*}{$\mathrm{i}_{2}$} & \multirow[t]{2}{*}{$q_{1}$} & $\mathrm{w}_{1}$ & 0,081 & \multirow[t]{6}{*}{$\mathrm{i}_{4}$} & \multirow[t]{2}{*}{$q_{1}$} & $\mathrm{w}_{1}$ & 0,206 \\
\hline & & $\mathrm{W}_{2}$ & 0,09 & & & $\mathrm{w}_{2}$ & 0,229 \\
\hline & \multirow[t]{2}{*}{$q_{2}$} & $w_{3}$ & 0,072 & & \multirow[t]{2}{*}{$q_{2}$} & $w_{3}$ & 0,183 \\
\hline & & $\mathrm{W}_{4}$ & 0,081 & & & $\mathrm{w}_{4}$ & 0,206 \\
\hline & \multirow[t]{2}{*}{$\mathrm{q}_{3}$} & W5 & 0,068 & & \multirow[t]{2}{*}{$q_{3}$} & $\mathrm{~W}_{5}$ & 0,172 \\
\hline & & W6 & 0,09 & & & W6 & 0,229 \\
\hline
\end{tabular}

Table 12. RM transport costs

\begin{tabular}{|c|c|c|c|}
\hline RM & Supplier & Plant & costtp ${ }_{c r}$ \\
\hline $\mathrm{C}_{1}$ & $\mathrm{r}_{1}$ & $\mathrm{p}_{1}$ & 0,24 \\
\cline { 3 - 4 } & $\mathrm{p}_{2}$ & 0,24 \\
\cline { 3 - 4 } & & $\mathrm{p}_{3}$ & 0,24 \\
\hline
\end{tabular}

Table 13. Amount $\left(\mathrm{m}^{2}\right)$ of product $i$ manufactured on production line / of production plant $p$ in time period $t$

\begin{tabular}{|c|c|c|c|c|c|c|c|c|}
\hline & & & \multicolumn{6}{|c|}{ Mpilpt } \\
\hline FG & Line & Plant & $t_{1}$ & $t_{2}$ & $t_{3}$ & $\mathrm{t}_{4}$ & $t_{5}$ & t6 \\
\hline \multirow[t]{2}{*}{$\mathrm{i}_{1}$} & $I_{3}$ & $\mathrm{p}_{2}$ & 1500,00 & 1500,00 & 1500,00 & 1800,45 & 2456,85 & 2631,58 \\
\hline & $I_{4}$ & $\mathrm{p}_{2}$ & 1500,00 & 1500,00 & 2204,08 & 1500,00 & 0,00 & 0,00 \\
\hline \multirow[t]{2}{*}{$i_{2}$} & $I_{1}$ & $p_{1}$ & 2533,33 & 3333,33 & 3333,33 & 3333,33 & 1896,82 & 2746,03 \\
\hline & $I_{6}$ & $p_{3}$ & 2182,08 & 2971,65 & 3333,33 & 2633,78 & 1500,00 & 1500,00 \\
\hline $\mathrm{i}_{3}$ & $\mathrm{I}_{2}$ & $p_{1}$ & 3158,73 & 4166,66 & 4166,66 & 3914,96 & 3738,09 & 4166,66 \\
\hline
\end{tabular}

Table 14. Amount $\left(\mathrm{m}^{2}\right)$ of subcontracted FG $i$ subcontracted to supplier $b$ for warehouse $a$ in time period $t$

\begin{tabular}{|c|c|c|c|c|c|c|c|c|}
\cline { 3 - 9 } \multicolumn{2}{c|}{} & \multicolumn{7}{c|}{ CSC $_{\text {ibat }}$} \\
\hline FG & Supplier & Warehouse & $\mathrm{t}_{1}$ & $\mathrm{t}_{2}$ & $\mathrm{t}_{3}$ & $\mathrm{t}_{4}$ & $\mathrm{t}_{5}$ & $\mathrm{t}_{6}$ \\
\hline $\mathrm{i}_{3}$ & $\mathrm{~b}_{1}$ & $\mathrm{a}_{1}$ & 100 & 0 & 0 & 0 & 0 & 0 \\
\hline $\mathrm{i}_{4}$ & \multirow{2}{*}{$\mathrm{b}_{1}$} & $\mathrm{a}_{1}$ & 397 & 616 & 570 & 616 & 751 & 726 \\
\cline { 3 - 10 } & & $\mathrm{a}_{2}$ & 286 & 234 & 280 & 234 & 99 & 124 \\
\hline
\end{tabular}


Table 15. Amount of the RM $c$ to be purchased and transported from supplier $r$ to production plant $p$ in time period $t$

\begin{tabular}{|c|c|c|c|c|c|c|c|c|}
\cline { 4 - 9 } \multicolumn{2}{c|}{} & \multicolumn{7}{c|}{ CTP crpt $_{4}$} \\
\hline RM & Supplier & Plant & $\mathrm{t}_{1}$ & $\mathrm{t}_{2}$ & $\mathrm{t}_{3}$ & $\mathrm{t}_{4}$ & $\mathrm{t}_{5}$ & $\mathrm{t}_{6}$ \\
\hline \multirow{2}{*}{ C1 } & \multirow{2}{*}{$\mathrm{r}_{1}$} & $\mathrm{p}_{1}$ & 67968,57 & 86916,66 & 86916,66 & 143268,25 & 85240,25 & 0,00 \\
\cline { 3 - 9 } & & $\mathrm{p}_{2}$ & 38600,00 & 36600,00 & 48723,58 & 36731,74 & 62078,91 & 0,00 \\
\cline { 3 - 9 } & & $\mathrm{p}_{3}$ & 73431,42 & 56483,33 & 44359,75 & 0,00 & 0,00 & 0,00 \\
\hline
\end{tabular}

Table 16. Inventory $\left(\mathrm{m}^{2}\right)$ of $\mathrm{FG} i$ in warehouse $a$ in time period $t$

\begin{tabular}{|c|c|c|c|c|c|c|c|}
\cline { 3 - 8 } \multicolumn{2}{c|}{} & \multicolumn{7}{c|}{ INAiat } \\
\hline $\mathrm{FG}$ & Warehouse & $\mathrm{t}_{1}$ & $\mathrm{t}_{2}$ & $\mathrm{t}_{3}$ & $\mathrm{t}_{4}$ & $\mathrm{t} 5$ & $\mathrm{t} 6$ \\
\hline \multirow{2}{*}{$\mathrm{i}_{1}$} & $\mathrm{a}_{1}$ & 2363 & 2156 & 2000 & 2000 & 2517,94 & 2000 \\
\cline { 2 - 8 } & $\mathrm{a}_{2}$ & 2000 & 2000 & 2000 & 2000 & 2000 & 2000 \\
\hline \multirow{2}{*}{$\mathrm{i}_{2}$} & $\mathrm{a}_{1}$ & 2000 & 2361 & 2000 & 2000 & 2000 & 2000 \\
\cline { 2 - 8 } & $\mathrm{a} 2$ & 2000 & 2000 & 2000 & 2000 & 2000 & 2000 \\
\hline \multirow{2}{*}{$\mathrm{i}_{3}$} & $\mathrm{a}_{1}$ & 1761 & 2013 & 1600 & 1600 & 1600 & 1600 \\
\cline { 2 - 8 } & $\mathrm{a}_{2}$ & 1600 & 1600 & 1600 & 1600 & 2128 & 1600 \\
\hline \multirow{2}{*}{$\mathrm{i}_{4}$} & $\mathrm{a}_{1}$ & 1696 & 1813 & 1783 & 1831 & 1823 & 1600 \\
\cline { 2 - 8 } & $\mathrm{a}_{2}$ & 1600 & 1600 & 1600 & 1600 & 1600 & 1600 \\
\hline
\end{tabular}

Table 17. Inventory of the RM $c$ in plant $p$

\begin{tabular}{|c|c|c|c|c|c|c|c|}
\cline { 3 - 8 } \multicolumn{2}{c|}{} & \multicolumn{7}{c|}{$\mathrm{INC}_{\mathrm{cpt}}$} \\
\hline $\mathrm{R} M$ & Plant & $\mathrm{t}_{1}$ & $\mathrm{t}_{2}$ & $\mathrm{t}_{3}$ & $\mathrm{t}_{4}$ & $\mathrm{t}_{5}$ & $\mathrm{t}_{6}$ \\
\hline \multirow{2}{*}{$\mathrm{C}_{1}$} & $\mathrm{p}_{1}$ & 2000,00 & 2000,00 & 2000,00 & 61145,46 & 81751,58 & 2000,00 \\
\cline { 2 - 8 } & $\mathrm{p}_{2}$ & 2000,00 & 2000,00 & 5533,78 & 2000,00 & 34105,26 & 2000,00 \\
\cline { 2 - 8 } & $\mathrm{p}_{3}$ & 46809,97 & 67039,11 & 70732,19 & 38600,00 & 20300,00 & 2000,00 \\
\hline
\end{tabular}

Table 18. Computational efficiency

\begin{tabular}{|c|c|c|c|c|c|c|c|}
\hline Model & Iterations & Variables & Integers & Constraints & Non-zero & Density(\%) & $\begin{array}{c}\text { Time } \\
\text { (seconds) }\end{array}$ \\
\hline MP-RDSINC & 440992 & 1584 & 1320 & 1650 & 4889 & 0,19 & 49,02 \\
\hline
\end{tabular}

Table 19. Inventory level 


\begin{tabular}{|c|c|}
\hline Item & $\begin{array}{c}\text { Inventory } \\
\text { Level }\end{array}$ \\
\hline $\mathrm{i}_{1}$ & 4172,82 \\
\hline $\mathrm{i}_{2}$ & 4060,16 \\
\hline $\mathrm{i}_{3}$ & 3383,66 \\
\hline $\mathrm{i}_{4}$ & 3357,66 \\
\hline $\mathrm{C} 4$ & 74002,89 \\
\hline
\end{tabular}

Table 20. Total net profit

\begin{tabular}{|l|r|}
\cline { 2 - 2 } \multicolumn{1}{c|}{} & MP-RDSINC \\
\hline Incomes & 1059935,65 \\
\hline Replenishment costs & 208156,59 \\
\hline Production costs & 381360,54 \\
\hline Inventory costs & 11259,79 \\
\hline Outsourcing costs & 36024,3 \\
\hline Set-up costs & 6463,63 \\
\hline Transport costs & 48438,35 \\
\hline Backorder costs & 0 \\
\hline Total costs & 691703,2 \\
\hline Profits & $\mathbf{3 6 8 . 2 3 2 , 4 5} €$ \\
\hline
\end{tabular}


1

2

3

4

5

6

7

8

9

10

11

12

13

14

15

16

17

18

19

20

21

22

23

24

25

26

27

28

29

30

31

32

33

34

35

36

37

38

39

40

41

42

43

44

45

46

47

48

49

50

51

52

53

54

55

56

57

58

59

60

\section{Figure Captions}

Figure 1: Multi-supplier, multi-plant, multi-type and multi-level distribution centres, multi-item and multi-period logistic model. 

COMPONENT SUPPLIER

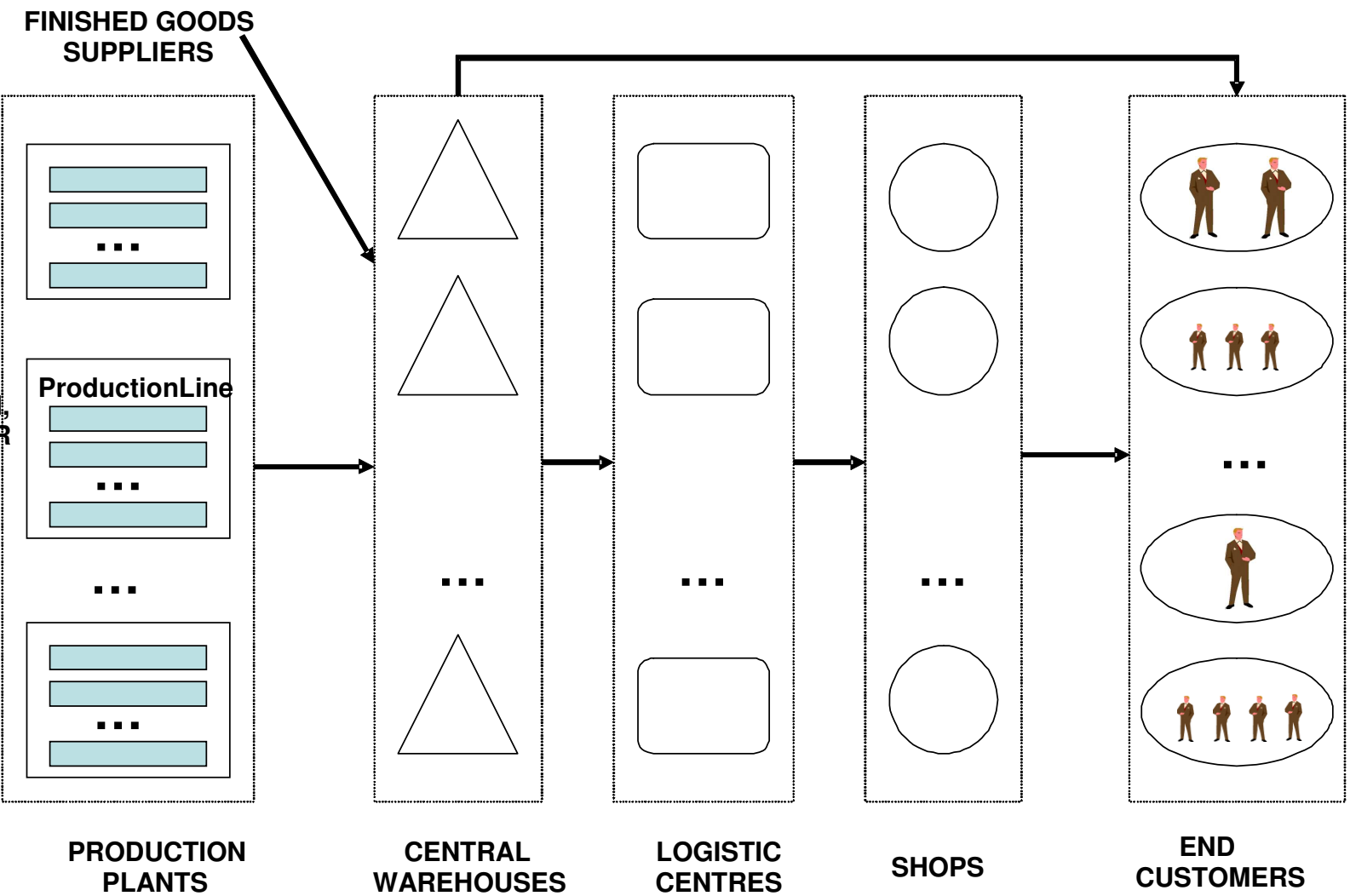

